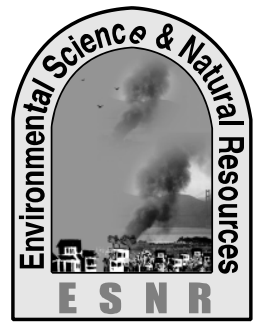

\title{
Food Security Status of Tribal People at Mohadevpur Upazila in Naogaon District
}

\author{
M. M. H. Sikder ${ }^{*}$, M. A. Baten ${ }^{2}$, M. A. Ali ${ }^{2}$ and P. K. Das ${ }^{2}$ \\ ${ }^{1}$ Interdisciplinary Center for Food Security (ICF), \\ ${ }^{2}$ Department of Environmental Science, Bangladesh Agricultural University, Mymensingh \\ "Corresponding author: mahade.hasan41@yahoo.com
}

\begin{abstract}
The study examines the food security analysis of households of tribal people at three villages of Mohadevpur Upazila of Naogoan District. Data were collected from a random sample of 63 where the total tribal people were 252. A structured interview schedule and focus group discussion were used for collecting data during July to September 2016. Food security condition of households of tribal people was measured on the basis of their per capita calorie consumption per day. Pearson's Product Moment Coefficient Correlation (r) was computed to explore relationship of the respondents' selected characteristics and their food security condition. The major findings of the study were that education level, house land size, cultivable area, annual household income, training experience, credit received and perceived strategies to increase food security had significant positive impact on food security (calorie intake) but age had significant negative impact on their household food security (calorie intake). Most of the households were (71percent) moderately food secured, 21 percent household had food secured and 8 percent households were low food secured per year. Government and NGOs should provide various types of training on agriculture and non-agriculture of tribal people. Government should take some safety net programs during climatic events such as drought, river erosion etc. Government, different NGOs and development agencies should give attention to improve their income through adopting some income generating activities.
\end{abstract}

Key words: Calorie intake, Food Security Status, Mohadevpur and Tribal people

\section{Introduction}

Bangladesh is an agriculture based country and it contributes 17 percent in national GDP (BBS, 2015). It remains highly food insecure in spite of important economic progress. Bangladesh is ranked 142th out of 188 countries in the 2014 Human Development Index (HDI), (UNDP, 2015). Bangladesh and deepened food insecurity. Unprecedented shocks to food security are not new to Bangladesh. Its history is dotted with famines, cyclones and floods, which have elicited mature responses in dealing with food crises (WFP, 2008). Nearly 40 percent of the population lives below the food consumption-based poverty line, lacking sufficient resources to afford diet of 2,122 kilocalories (kcal) per person per day, along with other basic necessities. Apart from the prevailing deficit in total calorie intake, the normal diet of Bangladeshi people is seriously imbalanced, with inadequate consumption of fat, oil and protein, and with more than 80 percent of calories derived from cereals. Women and children are especially vulnerable due to their greater nutritional requirements. This dietary imbalance reflects insufficient domestic production of non-cereal foods (pulses, oilseeds, fruits, meat, milk and eggs), low incomes, food preferences and lack of nutrition education (Hossain et al., 2005).

As the percentage of urban population increases, achieving higher food productivity and lower food prices will be difficult without the provision of proper agricultural incentives to farmers (Suryanarayanan, 2010). The major findings of the study were that about $68.33 \%$ of the respondents belonged to hard core poor whose average calorie intake was 1692.32 . There was $20 \%$ households having poor food consumption and $70 \%$ having borderline food consumption, $6.67 \%$ having low food consumption and $3.33 \%$ having high food consumption.
Diagne and Zeller (2001) studied about the impact of access to credit on income and food security in Malawi. The main finding of the paper was that access to formal credit, by enabling households to reduce their borrowing from informal sources, had marginally beneficial effects on household annual income. However these effects were very small and did not cause any significance difference between the per capita income, food security and nutritional status of credit program of members and non-members. Habib (2005) studied the political and economic condition of the tribal and non-tribal people of Bangladesh. The study revealed that the tribal and non-tribal people of Bangladesh have been living alongside peace and harmony over the ages. A fraction of tribal community has been trying to derive benefits by integrating communal violence. Such attitude jeopardizes the peaceful co-existence. To achieve desired agricultural production for gaining sustained food security, it is necessary to have a clear understanding about food security status of the tribal people. Thus, the study was undertaken to ascertain the food security status of the relationships of the selected characteristics of the heads of households with their household food security status.

\section{Methodology}

The aim of the study was to know the food security condition of tribal people. Preliminary visits were made for selecting study area and finally the study was conducted in Mohadevpur upazila in Naogaon district. Hamidpur, Juanpur, and Enaitpur villages were selected from many tribal areas because no research work has done based on food security condition in this area. In this study, 63 tribal households were randomly selected from three villages. The required data were collected during July to September 2016. In total there were 252 tribal people (head from each household) in this selected village which were considered as population of the study. Twenty five percent of the population was 
randomly selected by using a Table of Random Numbers. Personal interview and Focus Group Discussion methods were employed for data collection. Data were analyzed in accordance with objectives of the study. The dependent variable in this study was household food security status of selected tribal people. It was determined using the consumption approach. To obtain the actual calorie consumption by the household members, Household Calorie Acquisition method was used. First, the gross household food consumption of last 7 days was converted into calories. Finally, a concise figure for average calories consumed per person per day was calculated and compared with an estimate of threshold kilocalorie level requirement i.e. $2122 \mathrm{kcal}$ (HIES, 2010). The characteristics of the tribal people i.e. age, education level, family size, household size, cultivable area, annual income, training experience, credit received and perceived strategies to increase food security were the independent variables.
SPSS (Statistical package for social sciences) computer program was used to perform the data analysis. Pearson's Product Moment correlation co-efficient (r) was computed. Correlation analysis was used to find the relationship between food security status of tribal people and their personal, socio-economic characteristics of the tribal people on food security status of tribal people. Multiple regression analysis was carried out to determine the factors influencing calorie intake in individual levels. Food consumption scores were also used to determine calorie intake levels.

\section{Results and Discussion}

Characteristics of an individual greatly determine his behavior. In the present study 9 characteristics of the respondents were considered. The salient features of the characteristics of the tribal people and their classification based on the characteristics have been presented in Table 1.

Table 1. Classification of tribal people according to their selected characteristics

\begin{tabular}{|c|c|c|c|c|c|c|c|}
\hline Characteristics & $\begin{array}{l}\text { Scoring } \\
\text { system }\end{array}$ & \begin{tabular}{|l|} 
Range \\
Observed \\
(Possible)
\end{tabular} & Category & $\begin{array}{l}\text { Number } \\
(\mathrm{N}=63)\end{array}$ & Percent & Mean & SD \\
\hline \multirow[t]{3}{*}{ Age } & \multirow[t]{3}{*}{ Years } & \multirow{3}{*}{$\begin{array}{l}30-67 \\
\text { (Unknown) }\end{array}$} & Young $(\leq 35)$ & 12 & 19.05 & \multirow{3}{*}{49.4} & \multirow{3}{*}{10.47} \\
\hline & & & Middle-aged (36-55) & 30 & 47.62 & & \\
\hline & & & Old $(>55)$ & 21 & 33.3 & & \\
\hline \multirow[t]{3}{*}{ Education level } & \multirow{3}{*}{$\begin{array}{l}\text { Level of } \\
\text { schooling }\end{array}$} & \multirow{3}{*}{$\begin{array}{l}0-5 \\
\text { (Unknown) }\end{array}$} & Cannot read or write $(0)$ & 19 & 30.16 & \multirow{3}{*}{1.548} & \multirow{3}{*}{1.84} \\
\hline & & & Can sign only $(0.5)$ & 19 & 30.16 & & \\
\hline & & & Primary (1-5) & 25 & 39.68 & & \\
\hline \multirow[t]{3}{*}{ Family size } & \multirow[t]{3}{*}{ Numbers } & \multirow{3}{*}{$\begin{array}{l}1-7 \\
\text { (Unknown) }\end{array}$} & Small (1-4) & 37 & 58.73 & \multirow{3}{*}{4.46} & \multirow{3}{*}{1.28} \\
\hline & & & Medium (5-6) & 21 & 33.3 & & \\
\hline & & & Large (above 6) & 5 & 7.94 & & \\
\hline \multirow[t]{3}{*}{ Household land size } & \multirow[t]{3}{*}{ Decimal } & \multirow{3}{*}{$\begin{array}{l}\text { 3-20 } \\
\text { (Unknown) }\end{array}$} & Small (3-8) & 55 & 87.3 & \multirow{3}{*}{6.62} & \multirow{3}{*}{3.52} \\
\hline & & & Medium (9-15) & 5 & 7.94 & & \\
\hline & & & Large (above 15) & 3 & 4.76 & & \\
\hline \multirow[t]{3}{*}{ Cultivable area } & \multirow[t]{3}{*}{ Decimal } & \multirow{3}{*}{$\begin{array}{l}0-140 \\
\text { (Unknown) }\end{array}$} & Small (0-50) & 43 & 68.25 & \multirow{3}{*}{46.03} & \multirow{3}{*}{31.17} \\
\hline & & & Medium (51-99) & 14 & 22.2 & & \\
\hline & & & High (above 99) & 6 & 9.52 & & \\
\hline \multirow[t]{3}{*}{ Annual income } & \multirow{3}{*}{$\begin{array}{l}\text { Taka } \\
\text { (in "000") }\end{array}$} & \multirow{3}{*}{$\begin{array}{l}\text { 8-222 } \\
\text { (Unknown) }\end{array}$} & Small (8-100) & 49 & 77.8 & \multirow{3}{*}{91492.06} & \multirow{3}{*}{$\begin{array}{l}45350 . \\
92\end{array}$} \\
\hline & & & Medium (100-190) & 9 & 14.29 & & \\
\hline & & & Large (above 190) & 5 & 7.94 & & \\
\hline \multirow[t]{3}{*}{ Training experience } & Days & $3-28$ & Low (up to 10) & 39 & 61.9 & & \\
\hline & & (Unknown) & Medium(11-20) & 21 & 33.3 & 10.46 & 5.78 \\
\hline & & & High (above 20) & 4 & 6.35 & & \\
\hline & & & Small (up to 10 ) & 35 & 55.6 & & \\
\hline Credit received & $\begin{array}{l}\text { Iaka } \\
\text { in "OOn") }\end{array}$ & $0-40$ & Medium (11-25) & 26 & 41.27 & 11904.76 & 7482.8 \\
\hline & & & High (above 25 ) & 2 & 3.17 & & \\
\hline & Score & & Low ( 0-16) & 8 & 12.69 & & \\
\hline increase food security & peore & $2-40$ & Medium (17-32) & 49 & 77.8 & 22.25 & 7.02 \\
\hline & & & High (above 32) & 6 & 9.52 & & \\
\hline
\end{tabular}

$* \mathrm{SD}=$ Standard Deviation

\section{Food Security Situation of the Tribal People}

The household food security status of tribal people was measured in terms of household calories consumption per person per day. The household calories consumption per person per day in a household ranged from 900.21 to $2210.4 \mathrm{kcal}$. The average daily per capita calorie intake by households was estimated to be $1975.83 \mathrm{kcal}$ with a standard deviation of 204.67. The average was lower than the national average of 2318.3 kcal (HIES, 2010). 


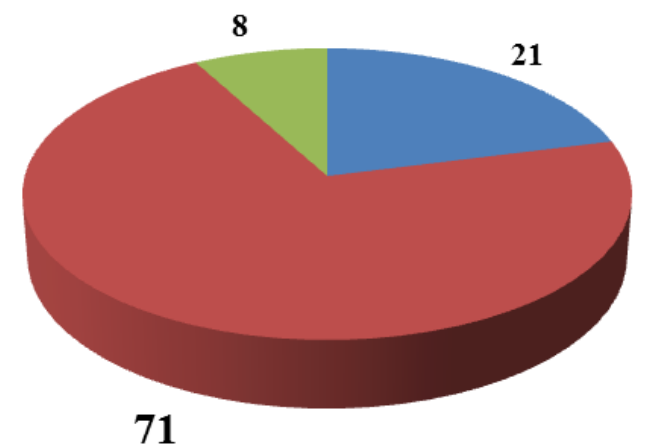

Fig. 1. Household food security status of the respondents

Graph shown that 21 percent of tribal people belonged to food secured, while 71 percent of tribal people belong to moderately food secured and 8 percent had low food secured. Highest percentage of food security status is medium level. Because of, they are shifting their occupation agriculture to other work. Such as, van driver, labor, shopkeeper etc. Findings show that food insecurity still lingers as a truth for the tribal people. Their access to food is hindered due to lack of purchasing capacity, lack of new technologies, lack of awareness and quite a few other factors including natural calamities and seasonal market fluctuation of commodities.

In 2004, eighty-eight percent of American households were food secured, meaning that they had access, at all times, to enough food for an active, healthy life for all households members. Selected households were food insecure at least some time during that year. The prevalence of food insecure rose from 11.2 percent of households in 2003 to 11.9 percent in 2004 and the prevalence of insecurity with hunger rose from 3.5 percent to 3.9 percent (USDA, 2004).
In 2011, the findings that 52.9 percent of the households were food secure and energy intake was $2122 \mathrm{kcal} /$ person/day. Food insecure households were 41.3 percent and consumed between 1805 and 2121 $\mathrm{kcal} /$ person/day and 5.8 percent households were severely food insecure and calorie intake was less than $1805 \mathrm{kcal} /$ person/day (Mahzabin, 2011).

Relationship between selected characteristics of the Tribal people and their household food Security Status Pearson's product moment correlation coefficient (r) was used to test the concerned research hypothesis in the relationship between the dependent and independent variables. The computed correlation coefficients were found which led to the following observations:

Age of the tribal people had negative significant relationships with their household food security status. Level of education, cultivable land size, annual income, training experience, credit received and strategies to increase food security had significant positive relationships with household food security status. It may aid to secure better food to the family.

Table 2. Correlation co-efficient between selected characteristics of the tribal people and their food security status

\begin{tabular}{|l|l|}
\hline Selected characteristics of & Correlation coefficient ('r') with 61 d.f. $(\mathrm{n}=63)$ \\
\hline Age & $-.354^{* *}$ \\
\hline Level of education & $.480^{* *}$ \\
\hline Family member & .085 \\
\hline House land size & $.301^{*}$ \\
\hline Cultivable land size & $.492^{* *}$ \\
\hline Annual income & $.633^{* *}$ \\
\hline Training experience & $.483^{* *}$ \\
\hline Credit received & $.637^{*}$ \\
\hline Strategies to increase food security & $.651^{* *}$ \\
\hline
\end{tabular}

** Correlation is significant at the0.01 level (2-tailed) * Correlation is significant at the0.05 level (2-tailed)

The major findings of the study were income, education, cultivable area and rented area had positive impact on calorie intake but age of the respondents and family size had negative impact (Rahman, 2013). The findings of the were that farmers education, farm size, annual family income, annual household expenditure, decision making ability, extent of contact with information sources, usefulness of contact with information sources, mass media exposure and strategic behavior had significant positive relationships with their households food security status, while household size and dependency ration had significant negative relationships with their household food security status (Mahzabin, 2011). 


\section{Conclusions}

The findings of the study revealed that 21 percent of tribal people belonged to food secured, while 71 percent of tribal people belong to moderately food secured and 8 percent had low secured. Thus it might be told that more than twenty percent of the tribal households remain under either food secured or severe food insecurity indicating a grave scenario in tribal people. Age of the tribal people had negative significant relationships with their household food security status. Level of education, cultivable land size, annual income, sanitary system, drinking water, training experience, credit received and strategies to increase food security had significant positive relationships with household food security status. It is true that sustainable income generation is crucial for ensuring access of tribal people, particularly landless, marginal and small tribal people, to their basic requirements including access to adequate food.

\section{References}

BBS. 2015. Yearbook of Agricultural Statistics. Bangladesh Bureau of Statistics, Ministry of Planning, Government of the People's Republic of Bangladesh, Dhaka.

Diagne, A. and Zeller, M. 2001. Access to Credit and its Impact on Welfare in Malawi. International Food Policy Research Institute 2033 K Street, N.W., Washington, D.C. USA.

Habib, N. I. 2005. A Comparative Study on political and economic condition of tribal and non-tribal people of CHTs. Editorial page, The New Nation, Dhaka, 28 July 2005.

HIES. 2010. Household Income \& Expenditure Survey. Bangladesh Bureau of Statistics, Government of the People's Republic of Bangladesh, Dhaka.
Hossain, M.; Naher, F. and Shahabuddin, Q. 2005. Food Security and Nutrition in Bangladesh: Progress and Determinants. Electronic Journal of Agricultural and Development Economics, 2(2): 103-132.

Mahzabin, A.; Kashem, M. A. and Miah, M. A. 2011. Household Food Security Status of Farmers in Selected Areas of Phulpur Upazila under Mymensingh District. Bangladesh Journal of Extension Education. 23(1-2): 61-66.

Rahman, M. A.; Abka, R.; Rahman, M. S. and Sarma, P. K. 2013. Poverty and food security analysis: A study of fishermen households in a selected area of Bangladesh. Journal of the Bangladesh Agricultural University, 11(2): 293-299.

Suryanarayanan, S. 2010. Innovations \& Food Security in Bangladesh. World Security Network .Retrieved from: http:// www. worldsecuritynetwork.com/showArticle3.cfm? article-id (12 March 2012).

UNDP. 2015. Human Development Index. United Nations Development Programme. New York. Retrieved from: http://hdr.undp.org/en/media/PR3-HDR10-HD1E-rev4.pdf (20 March 2015)

Nord, M.; Andrews, M. and Carlson, S. 2004. Household Food Security in the United States. United States Department of Agriculture.

WFP. 2008. UNHCR/WFP Joint Assessment Mission in Bangladesh. Retrieved from http://www.wfp.org/content/bangladeshunhcrwfp-joint-assessment-missionjune- 2008 (10 January 2012). 